\title{
Analisis Kualitas Air di KM 35 Desa Rantau Makmur Kecamatan Rantau Pulung Kabupaten Kutai Timur
}

\author{
Amprin $^{1}$ dan Dhani Aryanto ${ }^{2}$ \\ 1,2 Program Studi Teknik Pertanian, Sekolah Tinggi Pertanian Kutai Timur, Sangatta, \\ Kutai Timur, Kalimantan Timur \\ 1 email: amprin@stiperkutim.ac.id \\ 2 email: dhaniaryanto@stiperkutim.ac.id
}

\begin{abstract}
The aim of this study was to determine the water quality of the swamp KM35 by physical parameters, chemical parameters and biological parameters, and to determine the status of water quality swamp KM35 of water quality standards based on class IV for rice farming irrigation source. This research was conducted from September to October, 2015, in the swamp village KM35 Overseas Makmur Village of Rantau Pulung Subdistrict regency East Kutai. And the sample testing were conducted in the Laboratory of the Faculty of Marine Sciences and Fisheries Mulawarman Samarinda. The determination of the status of water quality using a scoring system storet US-EPA (Environment Protection Agency United Status) and refers to government regulation No.82 of 2001. The results of the analysis based on the parameters showed that the condition of the water quality standards by government regulation No. 82 of 2001. Physical parameters which include swamp water temperature $28.5^{\circ} \mathrm{C}, 4.75$ PtCo color, 183.6 NTU turbidity. Chemical parameters include pH 6.3, BOD 1:39 mg/l, COD 7:20 mg/l, DO $3.65 \mathrm{mg} / \mathrm{l}$, nitrate $2.89 \mathrm{mg} / \mathrm{l}$, below the limit of Manganese, Iron 12:58 mg/l, 5:33 Chloride mg/l, Nitrite $0.007 \mathrm{mg} / \mathrm{l}$, and Sulfate 10:37 mg/l. Biological parameters include total Cloriform $90 \mathrm{MPN} / 100 \mathrm{ml}$. The results of this analysis indicate the condition of the swamp water on the fourth grade good water quality status or meet quality standards, source of irrigation for agriculture, especially rice.
\end{abstract}

Keywords: water quality, system storet US-EPA, water quality

\begin{abstract}
ABSTRAK
Tujuan penelitian ini adalah untuk mengetahui kualitas air di rawa KM 35 berdasarkan parameter fisika, paramater kimia, dan parameter biologi, dan mengetahui status mutu air di rawa KM 35 berdasarkan standar kualitas air pada kelas IV untuk sumber irigasi pertanian tanaman padi. Penelitian dilaksanakan pada bulan September sampai Oktober 2015, di rawa KM 35 Desa Rantau Makmur Kecamatan Rantau Pulung Kabupaten Kutai Timur. Dan pengujian sampel dilakukan di Laboratorium Fakultas IImu Kelautan dan Perikanan Universitas Mulawarman Samarinda. Penentuan status mutu air dengan menggunakan metode storet sistem penilaian US-EPA (United Status Environment Protection Agency) dan mengacu pada peraturan pemerintah No.82 tahun 2001. Hasil analisis berdasarkan parameter menunjukan bahwa kondisi air memenuhi baku mutu standar kualitas air berdasarkan peraturan pemerintah No. 82 tahun 2001. Parameter fisika yang meliputi suhu air rawa $27,7^{\circ} \mathrm{C}$, warna $4,75 \mathrm{PtCo}$, Kekeruhan 183,6 NTU. Parameter kimia meliputi pH 6,3, BOD 1.39 mg/tt, COD 7,20 $\mathrm{mg} / \mathrm{lt}$, DO $3,65 \mathrm{mg} / \mathrm{lt}$, Nitrat 2,89 mg/tt, Mangan di bawah batas limit, Besi 0,58 mg/tt, Khlorida $5,33 \mathrm{mg} / \mathrm{lt}$, Nitrit $0,007 \mathrm{mg} / \mathrm{lt}$, dan Sulfat $10,37 \mathrm{mg} / \mathrm{tt}$. Parameter biologi meliputi Total Cloriform 90 MPN/100ml. Hasil analisis tersebut menunjukan kondisi air rawa pada kelas IV status mutu air baik atau memenuhi baku mutu, untuk sumber irigasi pertanian terutama tanaman padi.
\end{abstract}

Kata kunci: kualitas air, metode storet US-EPA, status mutu

\section{Pendahuluan}

Air merupakan sumber daya alam yang sangat penting karena dibutuhkan demi kelangsungan hidup di bumi bagi makhluk hidup, air pun tidak dapat dilepaskan dari kehidupan makhluk hidup. Salah satunya adalah tanaman yang membutuhkan air untuk 
kelangsungan hidupnya. Tanaman yang kekurangan air akan layu dan dapat juga mati. Oleh karena itu air harus selalu tersedia bagi tanaman. Ketersediaan air maupun penyebaran air dipermukaan bumi tidak seperti yang diharapkan karena tergantung pada jumlah, waktu, kuantitas dan kualitas air itu sendiri. Pertumbuhan dan perkembangan penduduk menuntut peningkatan penyediaan air, baik untuk sumber irigasi maupun untuk keperluan lainnya (Syafrizal, 2008).

Penyediaan kebutuhan air tersebut dapat diperoleh dari sungai, danau, waduk, rawa, dan sebagainya) yang terdapat pada air permukaan maupun air dalam tanah. Rawa merupakan perairan yang cukup luas, dimana rawa pada umumnya terdapat didataran rendah dengan sumber air dari air hujan, air laut baik berhubungan maupun tidak berhubungan dengan sungai serta relatif tidak dalam. Rawa biasanya juga memiliki dasaran lumpur maupun tumbuhan yang membusuk serta banyak vegetasi baik mengapung maupun yang mencuat (Pusat Litbang SDA, 2006).

Ketersediaan air ditentukan oleh kuantitas dan kualitasnya, air irigasi mempunyai standar kualitas tertentu agar dapat dimanfaatkan oleh tanaman tanpa menimbulkan dampak negatif selama pertumbuhannya. Sementara itu fungsi air bagi tanaman digunakan untuk pengangkutan unsur-unsur hara, asimilasi, bagian dari tubuh tumbuhan, dan untuk penguapan.

Salah satu aktivitas manusia yang memberikan pengaruh terhadap kualitas air adalah pemakaian bahan pestisida dan penggunaan pupuk anorganik pada lahan pertanian dan perkebunan kelapa sawit serta pohon karet yang ada disekitar rawa. Secara tidak langsung pada saat hujan, air hujan dapat membawa sisa bahan pestisida dan pupuk anorganik mengalir ke daerah rawa sehingga terjadi pencemaran. Semua jenis pestisida dan pupuk anorganik bersifat racun, apabila sampai masuk ke dalam air lingkungan pertanian secara berlebihan maka perlu adanya perlakuan khusus sebelum petani padi di sekitar rawa KM 35 mempergunakan sebagi sumber air irigasi. Tanaman padi akan terancam mengalami produksi lebih rendah apabila terjadi pencemaran air rawa. Namun belum ada data tentang kualitas air rawa di KM 35, untuk itu perlu dilakukan penelitian tentang analisis kualitas air rawa di KM 35 sebagai sumber irigasi pada pertanian di Desa Rantau Makmur. Adapun Tujuan Penelitian ini untuk mengetahui kualitas air rawa di KM 35 berdasarkan parameter fisika, kimia, dan biologi, serta mengetahui status mutu air rawa di KM 35 sebagai sumber irigasi pertanian tanaman padi sawah.

\section{$2 \quad$ Metodologi Penelitian}

Pelaksanaan penelitian ini dilakukan pada daerah Rantau Makmur yaitu Rawa di KM 35 Rantau Makmur Kecamatan Rantau Pulung Kabupaten Kutai Timur. Waktu pelaksanaan penelitian ini pada bulan September sampai Oktober 2015. 


\section{Pengumpulan Data}

Penelitian ini dilakukan dengan pengumpulan data primer dan sekunder. Pengumpulan Data Primer menggunakan Metode Observasi melalui pengamatan dan pencatatan secara sistematik terhadap pengambilan sampel air pada air rawa di tiga titik pengamatan. Data yang dikumpulkan adalah parameter fisika (Temperatur, warna, dan Kekeruhan), parameter kimia ( $\mathrm{pH}, \mathrm{DO}, \mathrm{BOD}, \mathrm{COD}$, Nitrat, Nitrit, Sulfat, Besi, Mangan, Khlorida), dan parameter Biologi (Total Coliform). Pengumpulan data sekunder menggunakan pengumpulan data-data standar kualitas air di perairan umum menurut peraturan pemerintahan No. 82 tahun 2001. Serta data metode indeks storet dalam sistem nilai US_EPA.

\section{Lokasi}

Lokasi pengambilan sampel air ditentukan berdasarkan tujuan pemeriksaan kualitas air. Obyek penelitian pada air rawa yaitu lokasi penyadapan air untuk pemanfaatan, ditengah rawa, dan sumber alamiah air yang belum tercemar. Sedangkan penentuan titik sampel dengan kedalaman air rawa $<10 \mathrm{~m}$, sampel air diambil pada 2 titik masing-masing pada permukaan dan dasar danau/rawa (Effendi, 2003).

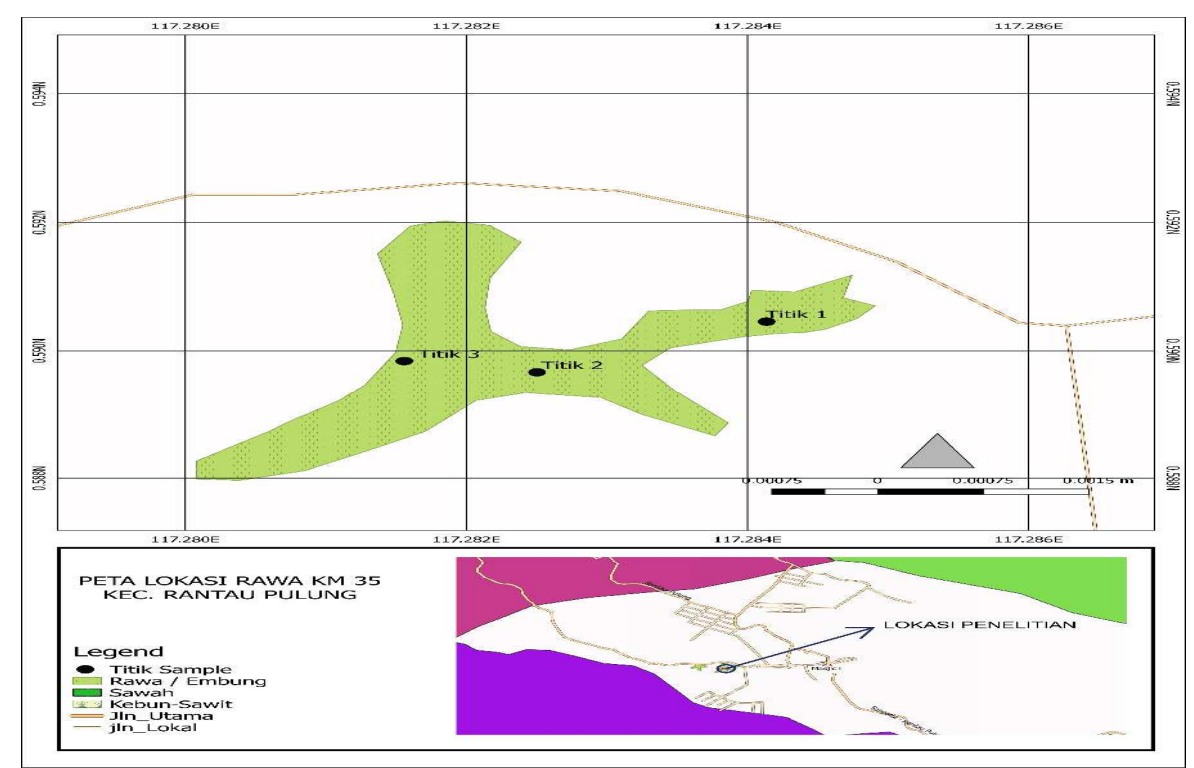

Gambar 1. Lokasi Pengambilan Sampel Air Rawa di KM 35

\section{Analisa Data}

Analisa data mengenai kondisi kualitas air rawa di KM 35 dilakukan melalui pendekatan penentuan status mutu air dengan metode indeks storet dengan Peraturan Pemerintah Nomor 82 tahun 2001 tentang baku mutu air yang digunakan untuk irigasi pertanian atau mengairi tanaman, sumber air minum, pembudidayaan perikanan, dan peternakan.

Analisa data kualitas air dengan metode indeks storet (Storage and Retrieval) adalah untuk mengetahui tingkat mutu kualitas air perairan setiap titik pengamatan. Pengamatan yang dilakukan melalui beberapa tahapan sebagai berikut: 
1. Melakukan pengumpulan data kualitas air

2. Membandingkan data hasil pengukuran dari masing-masing parameter air dengan nilai baku mutu yang sesuai dengan peruntukannya.

3. Jika hasil pengukuran memenuhi baku mutu maka diberi skor 0 .

4. Jika hasil pengukuran tidak memenuhi baku mutu maka diberi skor tertentu sesuai dengan sistem skor pada tabel 1.

Tabel 1. Penentuan Sistem Nilai Untuk Menentukan Status Mutu Air

\begin{tabular}{|c|c|c|c|c|}
\hline \multirow{2}{*}{$\begin{array}{l}\text { Jumlah } \\
\text { contoh }{ }^{1)}\end{array}$} & \multirow{2}{*}{ Nilai } & \multicolumn{3}{|c|}{ Parameter } \\
\hline & & Fisika & Kimia & Biologi \\
\hline \multirow[t]{3}{*}{$<10$} & Maksimum & -1 & -2 & -3 \\
\hline & Minimum & -1 & -2 & -3 \\
\hline & Rata-rata & -3 & -6 & -9 \\
\hline \multirow[t]{3}{*}{$\geq 10$} & Maksimum & -2 & -4 & -6 \\
\hline & Minimum & -2 & -4 & -6 \\
\hline & Rata-rata & -6 & -12 & -18 \\
\hline
\end{tabular}

Keuntungan menggunakan metode indeks storet salah satunya adalah menghasilkan atau angka yang dapat menggambarkan keseluruhan parameter-parameter karakteristik air sehingga diketahui status mutu kualitas air yang disesuaikan dengan peruntukannya guna menentukan status mutu air. Cara untuk menentukan status mutu air adalah membandingkan dengan menggunakan sistem nilai dari US-EPA (Environmental Protection Agency), dengan mengklasifikasikan mutu air.

Tabel 2. Penentuan Status Mutu Air Berdasarkan Metode Storet

\begin{tabular}{ccc}
\hline KELAS & SKOR & KRITERIA \\
\hline I & 0 & Memenuhi baku mutu \\
II & $-1 \mathrm{~s} / \mathrm{d}-10$ & Tercemar Ringan \\
III & $-11 \mathrm{~s} / \mathrm{d}-30$ & Tercemar Sedang \\
IV & $>-31$ & Tercemar Berat \\
\hline
\end{tabular}

\section{Hasil dan Pembahasan}

Desa Rantau Makmur adalah salah satu desa yang terdapat di Kecamatan Rantau Pulung, jarak dengan ibu kota Kecamatan Rantau Pulung $\pm 10 \mathrm{Km}$ dan $\pm 40 \mathrm{Km}$ dari ibu kota Kabupaten Kutai Timur. Secara geografis Desa Rantau makmur terletak diantara $117^{\circ} 10$ - $17^{\circ} 50 \mathrm{BT}$ dan $02^{\circ} 32-01^{\circ} 02 \mathrm{LU}$ pada ketinggian 0 sampai $65 \mathrm{mdpl}$. Desa Rantau Makmur beriklim tropis dengan hutan yang luas dan memiliki kelembaban udara yang relatif tinggi yaitu curah hujan antara $0-<2200 \mathrm{~mm}$ yang dipengaruhi musim hujan dan musim kemarau (NIKP. 2009). Desa Rantau Makmur berbatasan dengan :
1. Sebelah Utara
: Desa Kebun Agung
2. Sebelah Selatan
: Jalan HPH porodesa
3. Sebelah Timur
: Desa Mukti Jaya
4. Sebelah Barat
: HPH porodesa

Rantau makmur merupakan salah satu sentra produksi padi sawah di Kecamatan 
ISSN 2354-7251 (print)

Rantau Pulung dengan luas sawah $135 \mathrm{Ha}$, sebagian merupakan sawah tadah hujan, dan sawah irigasi $1 / 2$ teknis. Desa rantau makmur memiliki rawa yang disebut dengan rawa KM 35 dengan luas $\pm 8 \mathrm{Ha}$. Sebagian besar petani padi sawah memanfaatkan rawa ini sebagai sumber irigasi pertanian (Desa Rantau Makmur, 2012).

\section{Kualitas Air Rawa}

Kualitas air untuk pertanian adalah kesesuaian air untuk memenuhi fungsinya bagi tanaman. Kualitas yang baik tidak akan menimbulkan masalah karena tidak berpengaruh buruk terhadap pertumbuhan tanaman dan hasil panen. Makin buruk kualitas air makin berat masalah yang ditimbulkan dan makin sulit untuk diatasi. Hasil pengamatan dan pengukuran yang dilakukan pada rawa di KM 35 yaitu parameter fisika (Temperatur, Warna, dan Kekeruhan), parameter kimia ( $\mathrm{pH}, \mathrm{BOD}, \mathrm{COD}$, DO, Nitrat, Mangan, Besi, Klorida, Nitrit, dan Sulfat), dan parameter biologi (Total Coliform).

Tabel 3. Data Nilai Parameter Kualitas Air Rawa di KM 35

\begin{tabular}{|c|c|c|c|c|c|c|c|c|}
\hline \multirow{2}{*}{ Parameter } & \multirow{2}{*}{ Satuan } & \multirow{2}{*}{$\begin{array}{c}\text { Standar Baku } \\
\text { Air }\end{array}$} & \multicolumn{3}{|c|}{ Sampel } & \multicolumn{2}{|c|}{ Hasil Pengujian } & \multirow{2}{*}{ Rerata } \\
\hline & & & 1 & 2 & 3 & Max & Min & \\
\hline \multicolumn{9}{|l|}{ Parameter Fisika } \\
\hline Temperatur & ${ }^{\circ} \mathrm{C}$ & \pm 3 & & 27,2 & 28,5 & 28,5 & 27,2 & 27,7 \\
\hline Warna & PtCo & 200 & 3,21 & 2,85 & 8,21 & 8,21 & 2,85 & 4,75 \\
\hline Kekeruhan & NTU & & 65 & 44 & 442 & 442 & 44 & 183,6 \\
\hline $\begin{array}{l}\text { Kedalaman air rawa } \\
\text { Parameter Kimia }\end{array}$ & $\mathrm{m}$ & & 1,13 & 1,70 & 0,95 & & & \\
\hline $\mathrm{pH}$ & - & $6-9$ & 6,3 & 6,1 & 6,6 & 6,6 & 6,1 & 6,3 \\
\hline BOD & $\mathrm{mg} / \mathrm{lt}$ & 6 & 1,34 & 1,36 & 1,49 & 1,49 & 1,34 & 1,39 \\
\hline COD & $\mathrm{mg} / \mathrm{lt}$ & 50 & 5,60 & 7,80 & 8,20 & 8,20 & 5,60 & 7,20 \\
\hline DO & $\mathrm{mg} / \mathrm{lt}$ & 3 & 3,95 & 3,81 & 3,21 & 3,95 & 3,21 & 3,65 \\
\hline Nitrat $\left(\mathrm{NO}_{3}-\mathrm{N}\right)$ & $\mathrm{mg} / \mathrm{lt}$ & 20 & 2,87 & 2,71 & 3,09 & 3,09 & 2,71 & 2,89 \\
\hline Mangan & $\mathrm{mg} / \mathrm{lt}$ & $(-)$ & bdl & bdl & bdl & bdl & bdl & bdl \\
\hline Besi (Fe) & $\mathrm{mg} / \mathrm{lt}$ & $(-)$ & 0,66 & 0,54 & 0,55 & 0,66 & 0,54 & 0,58 \\
\hline Klorida (Cl) & $\mathrm{mg} / \mathrm{lt}$ & $(-)$ & 4 & 8 & 4 & 8 & 4 & 5,33 \\
\hline Nitrit $\left(\mathrm{NO}_{2}\right)$ & $\mathrm{mg} / \mathrm{lt}$ & 0,06 & 0,007 & 0,007 & 0,009 & 0,009 & 0,007 & 0,007 \\
\hline $\begin{array}{l}\text { Sulfat }\left(\mathrm{SO}_{4}\right) \\
\text { Parameter Biologi }\end{array}$ & $\mathrm{mg} / \mathrm{lt}$ & $(-)$ & 8,33 & 11,25 & 11,53 & 11,53 & 8,33 & 10,37 \\
\hline Total Coliform & $\mathrm{jml} / 100 \mathrm{ml}$ & 10000 & 60 & 150 & 60 & 150 & 60 & 90 \\
\hline
\end{tabular}

Sumber : Data Primer 2015

Dari data tabel 3. seluruh parameter yang di uji tidak ada perbedaan nilai yang terlalu besar, hal tersebut karena tata guna lahan daerah sampel I merupakan lahan yang belum digunakan kegiatan pertanian. Sampel 2 merupakan daerah tengah rawa, Sedangkan sampel 3 air rawa memiliki hasil pengukuran yang tinggi, hal ini disebabkan karena tata guna lahan pada daerah sampel 3 merupakan pintu air irigasi pertanian dan dekat dengan daerah perkebunan tanaman sawit, tanaman karet, serta persawahan.

\section{Parameter fisik Temperatur}

Temperatur air rawa berkisar antara $27.5^{\circ} \mathrm{C}-28.5^{\circ} \mathrm{C}$ yang merupakan suhu lingkungan penelitian, jika dibandingkan dengan standar kualitas air menurut PP Nomor 82 Tahun 2001 nilai temperatur yang dipersyaratkan berkisar antara deviasi $3-5^{\circ} \mathrm{C}$, suhu pada daerah penelitian memenuhi persyaratan semua kelas I-IV sehingga dapat digunakan untuk sumber air minum, prasarana rekreasi, peternakan, sumber air irigasi 
dan pembudidayaan ikan air tawar. Salah satu contoh pemanfaatan yang sesuai untuk daerah penelitian adalah budidaya ikan air tawar dengan suhu optimum $25-32^{\circ} \mathrm{C}$. Pada suhu rendah nafsu makan ikan akan turun yang mengakibatkan pertumbuhan ikan terganggu. Pada suhu tinggi ikan akan menunjukkan gejala kekurangan oksigen. Perubahan suhu secara tiba-tiba mengakibatkan ikan stres yang dapat mengakibatkan kematian (Andi dan M. Ghufran, 2007).

\section{a. Warna}

Warna air yang diamati secara visual berwarna kuning muda dan menyerupai urin, sedangkan hasil pengukuran di laboratorium mendapatkan nilai 2,85-8,21 PtCo. Standar warna yang diperlukan dalam kualitas air 100-250 PtCo, standar air yang memiliki kekeruhan rendah biasanya memiliki warna tampak dan warna sesungguhnya yang sama dengan standar. Warna perairan ditimbulkan adanya bahan organik dan anorganik karena keberadaan plankton, humus, dan ion-ion logam (Effendi, 2003).

\section{b. Kekeruhan}

Kemampuan cahaya matahari untuk menembus sampai kedasar perairan dipengaruhi oleh kekeruhan air. Kekeruhan sangat berpengaruh terhadap pertumbuhan biota air, karena sinar matahari yang datang ke air akan lebih banyak dihamburkan (Andi dan M. Ghufran, 2007). Kekeruhan di dalam air rawa disebabkan karena adanya pengikisan tanah sekitar rawa akibat erosi ataupun dengan terdapatnya aktifitas biota air. Menurut PP Nomor 82 Tahun 2001 nilai kekeruhan 5 NTU . Hasil pengukuran kekeruhan berkisar antara 44-442 NTU (Nephelometric turbidity unit).

\section{Parameter kimia}

a. $\mathrm{pH}$ (porosity of hydrogen)

Nilai $\mathrm{pH}$ atau derajat keasaman dari air merupakan salah satu sifat kimia yang penting. Air untuk irigasi sebaiknya bersifat netral, air irigasi yang asam banyak mengandung ion hidrogen dan air yang basa banyak mengandung ion hidroksida sehingga dapat mengurangi daya serap zat-zat yang diperlukan tanaman. Selain itu dapat merusak sel-sel tanaman sehingga metabolisme dari sel-sel terganggu dan mengurangi daya serap nutrisi (Andi dan M. Ghufran, 2007). Kriteria kualitas air nasional berdasarkan PP. Nomor 82 Tahun 2001 mensyaratkan pH air antara 5-9. Berdasarkan hasil pengukuran tiap sampel pada tabel 4.1. memenuhi persyaratan kualitas air dengan $\mathrm{pH}$ 6,1-6,6. Nilai $\mathrm{pH}$ daerah penelitian sesuai untuk semua kelas I-IV.

b. BOD (Biological Oxygen Demand)

BOD atau kebutuhan oksigen biologi merupakan jumlah oksigen yang dibutuhkan oleh mikroba aerob untuk mengoksidasi bahan organik menjadi karbondioksida dan air. Pada perairan alami yang berperan sebagai bahan organik adalah pembusukan tumbuhan dan hewan (Effendi, 2003). Nilai BOD air rawa di KM 35 adalah 1,34- 1,49 
$\mathrm{mg} / \mathrm{tt}$ jika dibandingkan dengan baku mutu untuk kelas I-IV yang tidak boleh melebihi dari $2 \mathrm{mg} / \mathrm{lt}$, maka nilai BOD daerah penelitian memenuhi persyaratan baku mutu. Menurut Lee (1998) mengklasifikasikan besarnya tingkatan pencemaran untuk organisme akuatik berdasarkan kandungan BOD menjadi empat golongan yaitu tidak tercemar ( $<3,0 \mathrm{mg} / \mathrm{lt})$, tercemar ringan (3,0-4,9 mg/lt), tercemar sedang (5,0-15,0 mg/lt) dan tercemar berat $(>15$ $\mathrm{mg} / \mathrm{lt})$. Oleh karena itu, rawa KM 35 tergolong perairan dengan kualitas air tidak tercemar.

c. COD (Cemical Oxygen Demand)

COD (Cemical Oxygen Demand) merupakan jumlah oksigen yang dibutuhkan agar bahan buangan yang ada didalam air dapat teroksidasi melalui reaksi kimia. COD yang aman untuk irigasi pertanian adalah kurang dari 100 mg/lt (Effendi, 2003).

Dari hasil pengujian sampel air rawa KM 35 menunjukkan bila dibandingkan baku mutu air kelas I-IV menurut PP No. 82 Tahun 2001 nilai COD daerah penelitian tidak melebihi nilai baku mutu air. Nilai COD masing-masing sampel adalah 5,60 mg/lt, 7,80 $\mathrm{mg} / \mathrm{lt}$ dan $8,20 \mathrm{mg} / \mathrm{lt}$.

d. DO (Disolved Oxygen)

DO atau oksigen terlarut merupakan salah satu parameter penting dalam analisis kualitas air. Nilai DO yang biasanya diukur dalam bentuk konsentrasi ini menunjukkan jumlah oksigen yang tersedia dalam suatu badan air. Semakin besar nilai DO pada air, mengindikasikan air tersebut memiliki kualitas yang bagus. Sebaliknya jika nilai DO rendah dapat diketahui bahwa air tersebut telah tercemar (Erwan, 2004). Hasil pengukuran air rawa di KM 35 memilki kadar DO sebesar 3,95 mg/lt, 3,81 mg/lt dan 3,21 $\mathrm{mg} / \mathrm{tt}$, jika dibandingkan dengan standar kualitas air yang baik menurut PP Nomor 82 Tahun 2001 kadar DO daerah penelitian memenuhi kelas III dan IV 0-6 mg/lt.

e. Nitrat $\left(\mathrm{NO}_{3}\right)$

Hasil pengukuran nitrat sampel I adalah 2,87 mg/lt, sampel 2 adalah 2,71 mg/t dan sampel 3 adalah 3,09 mg/lt. Berdasarkan standar kualitas air kandungan nitrat yang dibutuhkan 10-20 mg/lt, sehingga kandungan nitrat air rawa di KM 35 memenuhi persyaratan yang telah ditentukan. Kandungan nitrat merupakan bentuk senyawa nitrogen diperairan alami dan nutrien utama bagi pertumbuhan tanaman. Konsentrasi nitrat dalam perairan tinggi karena pengaruh dari pembusukan sisa tanaman dan hewan, pembuangan industri, pengotoran lahan pertanian yang berasal dari pupuk (Kristanto, 2000).

f. Nitrit $\left(\mathrm{NO}_{2}\right)$

Nitrit merupakan bentuk peralihan antara amonia dan nitrat. Ion nitrit dapat berperan sebagai sumber nitrogen bagi tanaman. Kadar nitrit pada perairan relatif kecil karena segera dioksidasi menjadi nitrat. Perairan alami mengandung nitrit sebesar 0,01 $\mathrm{mg} / \mathrm{tt}$ dan sebaliknya tidak melebihi $0,06 \mathrm{mg} / \mathrm{tt}$. Kadar nitrit yang lebih dari 0,05 mg/lt dapat bersifat toksik bagi organisme perairan yang sangat sensitif. Untuk kepentingan 
peternakan, kadar nitrit sekitar $10 \mathrm{mg} / \mathrm{lt}$ masih dapat ditolerir, untuk keperluan air minum WHO merekomendasikan kadar nitrit sebaiknya tidak lebih dari 1 mg/lt (Effendi, 2003).

Berdasarkan hasil pengujian kadar nitirit pada sampel adalah 0,007-0,009 mg/t, jika dibandingkan dengan PP No 82 Tahun 2001 pada semua kelas dengan nilai maksimum 0,06 mg/lt kualitas air rawa KM 35 dapat dimanfaatkan untuk air minum, kegiatan pertanian dll.

\section{g. Mangan (Mn)}

Mangan merupakan nutrien renik yang esensial bagi tumbuhan. Logam ini berperan dalam pertumbuhan dan merupakan salah satu komponen penting pada sistem enzim. Mangan dapat mengakibatkan pertumbuhan terhambat serta terganggunya sistem saraf dan proses reproduksi. Pada tumbuhan, mangan merupakan unsur esensial dalam proses metabolisme. Kadar mangan untuk irigasi pertanian adalah 0,2 $\mathrm{mg} / \mathrm{lt}$ untuk tanah yang bersifat asam, dan $10 \mathrm{mg} / \mathrm{lt}$ untuk tanah yang bersifat netral (Effendi, 2003). Berdasarkan PP No. 82 Tahun 2001 kadar mangan yang dibutuhkan 0,1 mg/tt, hasil pengukuran dibawah batas limit sehingga aman untuk digunakan sesuai peruntukkannya.

h. Besi (Fe)

Besi merupakan salah satu unsur hara ensesial bagi tumbuhan. Dalam tanaman besi berfungsi sebagai penyusun klorofil dan berperan dalam perkembangan kloroplas termasuk algae. Pada tumbuhan besi berperan dalam sistem enzim dan transfer electron pada proses fotosintesis. Namun kadar besi yang berlebihan dapat menghambat fiksasi unsur lainnya. Kadar besi pada perairan yang cukup mendapat aerasi (aerob) hampir tidak pernah lebih dari $03 \mathrm{mg} / \mathrm{lt}$. Kadar besi pada perairan alami berkisar antara 0,05-0,2 $\mathrm{mg} / \mathrm{t}$. Pada air tanah dalam dengan kadar oksigen yang rendah, kadar besi dapat mencapai $10-100 \mathrm{mg} / \mathrm{lt}$, sedangkan pada perairan laut sekitar 0,01 mg/t. Air hujan mengandung besi sekitar 0,05 mg/lt. Kadar besi > 1,0 mg/lt dianggap membahayakan kehidupan organisme akuatik. Air yang diperuntukan bagi air minum sebaiknya memiliki kadar besi kurang dari 0,3 mg/t dan perairan yang diperuntukkan bagi keperluan pertanian sebaiknya memiliki kadar besi tidak lebih dari 20 mg/lt (Effendi, 2003).

Berdasarkan hasil pengukuran nilai besi pada sampel I 0,66 mg/lt, sampel II 0,54 $\mathrm{mg} / \mathrm{lt}$, dan sampel III 0,55 mg/lt, memenuhi persyaratan untuk sumber irigasi pertanian. Sedangkan untuk sumber air minum tidak memenuhi persyaratan karena melebihi baku mutu berdasarkan PP No.82 Tahun 2001 kandungan besi yang dibutuhkan 0,3 mg/lt untuk sumber air minum.

i. Klorida $(\mathrm{Cl})$

Klorida merupakan ion yang sangat mudah larut dalam air sehingga dalam air alami selalu terdapat klorida dalam kadar yang bervariasi. ion klorida dalam air dapat terserap oleh akar tanaman dan terakumulasi pada daun. Akumulasi yang berlebihan 
dapat menyebabkan daun rusak seperti terbakar. Kadar klorida tinggi yang diikuti oleh kadar kalsium dan magnesium dapat meningkatkan sifat korosivitas air. Hal ini terjadinya perkaratan peralatan logam. Kadar klorida $>250 \mathrm{mg} / \mathrm{lt}$ dapat memberikan rasa asin pada air. Perairan yang diperuntukan bagi keperluan dosmetik, termasuk air minum, pertanian, dan industri, sebaiknya memiliki kadar klorida lebih kecil dari 100 mg/lt. Keberadaan klorida dalam air menunjukan bahwa air tersebut telah mengalami pencemaran atau mendapatkan rembesan dari air laut (Effendi, 2003). Nilai klorida dari hasil pengukuran 4$8 \mathrm{mg} / \mathrm{lt}$ pada tabel 4.1. memenuhi persyaratan, sesuai dengan Peraturan Pemerintah Nomor 82 Tahun 2001 dengan kadar klorida 600 mg/lt.

j. Sulfat $\left(\mathrm{SO}_{4}\right)$

Sulfat merupakan unsur yang diperlukan tanaman, yang berfungsi untuk membentuk protein, enzim, dan komponen-komponen membran. Sulfat terjadi secara alami pada sebagian besar ditanah. Pada tingkat tinggi sulfat dapat memberikan zat rasa. Orang-orang yang tidak terbiasa untuk minum air dengan kadar sulfat dapat mengalami diare dan dehidrasi (Kristanto, 2000). Berdasarkan hasil pengukuran nilai sulfat pada masing-masing sampel 8,33-11,53 mg/lt, yang sesuai dengan standar kualitas air berdasarkan PP No. 82 Tahun 2001 yaitu 400 mg/lt.

\section{Parameter Biologi}

Berbagai organisme dapat hidup dalam perairan, baik organisme yang bersifat patogen maupun tidak.sumber utama patogen adalah kotoran, baik kotoran hewan maupun manusia. Total cloriform merupakan indikator bakteri pertama yang digunakan untuk menentukkan aman tidaknya suatu perairan. Bila total cloriform dalam air ditemukan dalam jumlah yang tinggi maka kemungkinan terdapat adanya bakteri patogenik seperti giardia dan cryptosporidium didalamnya (Putra, 2011).

Hasil pengukuran dari masing-masing sampel pada tabel 4.1. 60-150 jml/100ml memiliki nilai yang memenuhi persyaratan, menurut PP Nomor 82 Tahun 2001 dengan nilai Total Cloriform 1000-10000 jml/100ml yang sesuai dengan peruntukan sumber air minum, pembudidayaan perikanan, peternakan, prasarana rekreasi dan sumber irigasi.

\section{Analisa Metode Indeks Storet}

Penerapan penentuan kualitas air menurut metode indeks storet ini dilakukan pada air rawa di KM 35. Penerapan status mutu air dapat dilihat pada tabel 3.1 untuk menghitung skor masing-masing tiap parameter. Pengambilan sampel air diambil sebanyak 3 sampel. Dari hasil pengukuran masing-masing sampel dapat dijadikan nilai maksimum didapat dari nilai tertinggi dari hasil pengukuran, nilai minimum didapat nilai terendah dari hasil pengukuran, dan nilai rerata didapat dari penjumlahan seluruh hasil pengukuran sampel kemudian dibagikan banyaknya sampel. Hasil perhitungan metode indeks storet disajikan pada Tabel 4 berikut 
Tabel 4. Kriteria Status Mutu Air

\begin{tabular}{cc}
\hline Kriteria Mutu Air & Skor Storet \\
\hline Kelas I & -20 \\
Kelas II & -2 \\
Kelas III & 0 \\
Kelas IV & 0 \\
\hline Sumber : Data Primer yang diolah dengan Metode Storet
\end{tabular}

Kriteria mutu air pada kelas I total score -20, menunjukkan bahwa air rawa dikatagorikan tercemar sedang. Hal ini menunjukan bagi peruntukan air baku air minum, perlu dilakukan pengolahan terlebihan dahulu untuk mengurangi kadar limbah yang terkandung di air rawa, sehingga layak untuk dikonsumsi. Nilai kadar besi $0,58 \mathrm{mg} / \mathrm{lt}$ yang melebihi baku mutu standar. Kadar besi meningkat disebabkan karena keadaan struktur tanah dalam air yang merupakan campuran lempung gambut dengan sedikit berpasir. Metode untuk penurunan kadar besi adalah proses penyaringan merupakan bagian dari pengolahan air yang pada prinsipnya adalah untuk mengurangi bahan-bahan organik maupun bahan-bahan an organik yang berada dalam air. Penghilangan zat padat tersuspensi dengan penyaringan memiliki peranan penting, baik yang terjadi dalam pemurnian air tanah maupun dalam pemurnian buatan di dalam instalasi pengolahan air.

Bahan yang dipakai sebagai media saringan adalah pasir yang mempunyai sifat penyaringan yang baik, keras dan dapat tahan lama dipakai bebas dari kotoran dan tidak larut dalam air. Sedangkan pada kelas II oksigen terlarut rendah total score -2, bahwa air rawa dikatagorikan tercemar ringan. Bagi peruntukan prasarana/sarana rekreasi air, pembudidayaan ikan air tawar, peternakan, air untuk mengairi pertanaman, dan atau untuk peruntukan lain yang mempersyaratkan mutu air yang sama dengan kegunaan tersebut. Untuk budidaya perikanan dengan nilai rerata DO 3,65 mg/lt sudah tidak sesuai, karena untuk berkembang secara baik DO optimal $>4 \mathrm{mg} / \mathrm{lt}$.

Hal tersebut perlu dilakukan pengolahan terlebih dahulu seperti peningkatan nilai oksigen terlarut dengan Aerator kincir, yang merupakan alat mekanik yang berfungsi untuk meningkatkan nilai oksigen air sehingga lebih banyak oksigen yang terlarut dalam air. Kincir air bekerja mengangkat air ke udara untuk disemburkan sehingga akan memperbesar luas permukaan kontak udara dan air. Nilai DO jumlahnya dapat berkurang disebabkan oleh beberapa hal antara lain: respirasi hewan dan tumbuhan (seperti tanaman air dan alga), dekomposisi bahan organik yang membutuhkan oksigen, reduksi yang disebabkan oleh gas-gas lainnya di dalam air (Andi dan M. Ghufran, 2007).

Hasil pengukuran pada kelas III dan IV seluruh parameter tidak melebihi baku mutu yang disyaratkan, total score 0 menunjukan air rawa di KM 35 dikatagorikan memenuhi baku mutu bagi kegiatan pembudidayaan ikan dan peternakan serta bagi kegiatan pertanian dan pertanaman. Kualitas air untuk pembudidayaan ikan tawar dan sumber irigasi pertanian adalah temperatur berkisar antara $25-32^{\circ} \mathrm{C}$ untuk suhu optimun, 
pH air antara 5-9, nilai COD tidak lebih dari $100 \mathrm{mg} / \mathrm{lt}$ untuk sumber irigasi, nilai nitrat tidak lebih dari $20 \mathrm{mg} / \mathrm{lt}$, nilai nitrit tidak lebih dari 0,06 mg/lt, kadar klorida yang baik untuk sumber irigasi pertanian yaitu sekitar $100 \mathrm{mg} / \mathrm{lt}$.

\section{Kesimpulan}

Analisis kualitas air rawa di KM 35 mendapatkan hasil pengukuran dibawah nilai standar baku mutu air tetapi memenuhi baku mutu untuk kelas III dan IV (Sebagai sumber irigasi pertanian, Peternakan, Perikanan dll). Parameter fisika yaitu temperatur, warna dan kekeruhan; Parameter kimia yaitu $\mathrm{pH}, \mathrm{DO}, \mathrm{BOD}, \mathrm{COD}$, Nitrat, Besi, Klorida, Nitrit, Sulfat, dan hasil pengukuran mangan dibawah batas limit. Sedangkan untuk parameter biologi yang digunakan adalah Total Coliform. Status mutu air rawa di KM 35 pada kelas III dan IV status mutu air baik atau memenuhi baku mutu, untuk sumber irigasi pertanian terutama tanaman padi.

\section{Daftar Pustaka}

Andi, B. T. \& M. Ghufran. (2007). Pengelolaan Kualitas Air dalam Budidaya Perairan. Rineka Cipta: Jakarta

Desa Rantau Makmur. (2012). Profil Desa Rantau Makmur. Desa Rantau makmur Kecamatan Rantau Pulung.

Hefni, E. (2003). Telaah Kualitas Air, Bagi Pengelolaan Sumber Daya dan Lingkungan Perairan. Kanisius: Yogyakarta.

Erwan, Y. (2004). Analisis Kualitas Air Keluaran Kolam Ikan Air Deras Pada Irigasi Bandar Kampus. Skripsi. FAPERTA-UNAND: Padang.

Kristanto. (2000). Unsur-unsur Senyawa Kimia. Bumi Aksara: Jakarta.

Lee, R. (1998). Hidrologi Hutan. Yogyakarta: Gadjah Mada University Press

NIKP. (2009). Curah Hujan Kecamatan Rantau Pulung Kabupaten Kutai Timur. Kabupaten Kutai Timur.

Nellawaty. (2007). Analisis Kualitas Air dan Struktur Komunitas Plankton di Sekitar Industri Cold Storage pada Sungai Mahakam di Kecamatan Anggana. Tesis Magister Ilmu Lingkungan-UNMUL: Samarinda.

Departemen Pekerjaan Umum RI. (2001). Standar Kualitas Air Diperairan Umum. Peraturan Pemerintah No. 82. Departemen Pekerjaan Umum RI: Jakarta

Pusat Litbang SDA. (2006). Pengelolaan Danau dan Waduk di Indonesia. Badan Lingkungan Keairan: Jakarta.

Putra, A. (2011). Manfaat dan Bahaya Bakteri E. Coli. http://www.emingko.com/2011/06/.html\#ixzz2Me6MTA5s

Safrizal. (2009). Analisis Kualitas Air Batang Pelangai untuk Sumber Air Irigasi Sawah di Kenagarian Pelangai Kecamatan Ranah Pesisir. Skripsi. FAPERTA - UNAND: Padang. 